\section{Morbidity and mortality associated with injuries: results of the Global Burden of Disease study in Brazil, 2008}

\author{
Diferenciais de morbimortalidade por causas \\ externas: resultados do estudo Carga Global de \\ Doenças no Brasil, 2008
}

\author{
Morbimortalidad por las causas externas: \\ resultados del estudio Carga Global de las \\ Enfermedades en Brasil, 2008
}

\begin{abstract}
The aim of this study was to estimate the global burden of disease from external causes in 2008 in Brazil, based on DALYs (disability-adjusted life years). YLLs (years of life lost) were estimated according to the method proposed by Murray \& Lopez (1996). Meanwhile, the method for estimating YLDs (years lived with disability) included methodological adjustments taking the Brazilian reality into account. The study showed a total of 195 DALYs per 100 thousand inhabitants, of which 19 DALYs were related to external causes. Among YLLs, 48\% were from unintentional causes and 52\% from intentional causes. Among YLDs, unintentional causes predominated, with 95\%. The share of YLLs in DALYs was $90 \%$. The cause with the highest proportion of YLLs was "homicide and violence" (43\%), followed by "road traffic accidents" (31\%). Falls accounted for the highest share of YLDs (36\%). The sex ratio (male-to-female) was 4.8 for DALYs, and the predominant age bracket was 15-29 years. Since external causes are avoidable, the study provides potentially useful information for policymakers in public security and health.
\end{abstract}

Cost of Illness; External Causes; Homicide; Accidents

\author{
Mônica Rodrigues Campos 1 \\ Vanessa dos Reis von Doellinger 1 \\ Luiz Villarinho Pereira Mendes 1 \\ Maria de Fatima dos Santos Costa 2 \\ Thiago Góes Pimentel 1 \\ Joyce Mendes de Andrade Schramm 1
}

\section{Resumo}

O objetivo do artigo é estimar a carga global de doença para causas externas em 2008, no Brasil. A metodologia empregada estimou o DALY (anos de vida perdidos ajustados por incapacidade). $O$ método de estimação dos anos de vida perdidos (YLL) foi o proposto por Murray \& Lopez (1996). Entretanto, para estimar os anos de vida vividos com incapacidade (YLD) foram aplicados refinamentos metodológicos considerando-se a realidade brasileira. Estimaram-se 195 DALY por 100 mil habitantes, sendo 19 DALY relacionados às causas externas. OYLL compôs-se de 48\% de causas não intencionais e 52\% intencionais. Já no YLD, as não intencionais predominaram com 95\%. A participação do YLL no DALY foi de 90\%. A causa com maior proporção de YLL foi "homicídio e violência" (43\%), seguida por "acidentes de trânsito" (31\%). As quedas representam a maior proporção de YLD (36\%). Observou-se uma razão de masculinidade de 4,8 no DALYe a faixa etária predominante foi de 15-29 anos. Sendo as causas externas evitáveis, tem-se importantes subsídios para os formuladores de políticas de segurança pública e de saúde.

Efeitos Psicossociais da Doença; Causas Externas; Homicídio; Acidentes 


\section{Introduction}

Injuries from external causes kill more than five million people a year worldwide, representing 9\% of world mortality. Millions of more survivors are harmed, requiring hospitalization and outpatient and emergency care 1,2 .

In Brazil, data from the Ministry of Health show that external causes claimed more than 145 thousand victims in 2011, corresponding to the third leading cause of death in the country $(12 \%$ of the total) and accounting for some one million hospitalizations (approximately $9 \%$ of the total), as the fifth leading cause of hospitalization in the Brazilian Unified National Health System (SUS) (Departamento de Informática do SUS. Banco de Dados do Sistema Único de Saúde. http:/ /www. datasus.gov.br, accessed 22/Oct/2013). In addition, these figures do not include victims that did not require hospitalization or that did not even use the health system.

The Global Burden of Disease study ${ }^{3}$ classifies external causes as intentional and unintentional, including the entire Chapter XX of the International Classification of Diseases, 10th Revision (ICD-10). The group of unintentional causes includes "road traffic accidents", "accidental poisoning", falls, burns, frostbite, drowning, submersion, "complications of medical care", and "others". Meanwhile, intentional causes include "homicide and violence", "suicide and self-inflicted injuries", and "legal interventions and wars".

A large proportion of survivors of such injuries suffer temporary or permanent disabilities, often jeopardizing their work capacity and quality of life. External causes have a huge impact on the economy and the population's health conditions. The effects extend beyond individual and collective suffering, threatening people's culture and way of live 4 .

It is thus extremely important to use a method capable of accurately computing morbidity and mortality data, considering the years of life lost by the population to disability or death, providing relevant information for priority-setting and the development of policies focused on the prevention, control, and monitoring of injuries from external causes.

The Global Burden of Disease study was developed in this context as part of a large world health assessment by Murray \& Lopez ${ }^{3}$ that introduced the indicator called DALY (disabilityadjusted life year). This indicator is the sum of two components: (1) YLL; years of life lost and (2) YLD; years lived with disability. Years of life lost to diseases, injuries, and sequelae are estimated by clinical and epidemiological parameters: incidence, prevalence, case-fatality, remission, duration, and proportion of cases treated. Diseases and sequelae, in turn, are subdivided into three major analytical groups: I - Communicable diseases, maternal/perinatal conditions, and nutritional conditions; II - Noncommunicable diseases; and III - External causes.

According to the Global Burden of Disease study held in 2010 1, approximately three hundred million years of life were lost due to injuries from external causes, representing $11 \%$ of all estimated DALYs in the world.

Brazil has conducted two editions of the Global Burden of Disease study, the first with estimates for the reference period of 1998 (Gadelha AMJ, Leite IC, Valente JG, Schramm JMA, Portela MC, Campos MR, et al. Relatório Final do Projeto Estimativa da Carga de Doenças do Brasil, 1998. Rio de Janeiro: Escola Nacional de Saúde Pública Sergio Arouca, Fundação Oswaldo Cruz; 2002) and the most current one for the year 2008 (Leite IC, coordinator. Relatório Final. Carga de Doenças do Brasil, 2008. Rio de Janeiro: Escola Nacional de Saúde Pública Sergio Arouca, Fundação Oswaldo Cruz/Núcleo de Pesquisa em Métodos Aplicados aos Estudos de Carga Global de Doença; 2013). The aim of the current article is to present the profile on burden of disease from external causes, according to age bracket, sex, and major geographic regions of the country.

\section{Material and methods}

This article is nested in the study Global Burden of Disease-Brazil 2008, using the methodology proposed by Murray \& Lopez 3 to estimate burden of disease, with some specificities described below.

Since the DALY indicator consists of the sum of the components of mortality (YLL) and morbidity (YLD), different procedures were necessary to generate them. Both estimates considered the three-year period including 2007, 2008, and 2009.

To elaborate YLL, information on deaths was obtained from the Mortality Information System (SIM) for the reference period, and life expectancy by sex and age bracket was used in the estimation methodology presented in the report Global Burden of Disease-Brazil 2008 (Leite IC, coordinator. Relatório Final. Carga de Doenças do Brasil, 2008. Rio de Janeiro: Escola Nacional de Saúde Pública Sergio Arouca, Fundação Oswaldo Cruz/Núcleo de Pesquisa em Métodos Aplicados aos Estudos de Carga Global de Doença; 2013).

Construction of the YLD indicator used data from the Hospital Information System of the Brazilian Unified National Health System (SIH/SUS). 
Social-demographic and diagnostic information was used to disaggregate parameters measured for hospitalizations during the reference period, excluding deaths. Since the SIH/SUS database only covers hospitalizations in the public sector, the coverage factor for the Unified National Health System from the year 2008 was applied to estimate the number of hospitalizations in the private sector 5 . In addition, the SIH/SUS only generates data on hospitalizations, which would tend to skew calculations of YLD, since it is known empirically that many victims of external causes are treated in emergency services without being hospitalized 6 .

In order to improve calculation of YLD, information was used on victims of accidents and violence treated in emergency services, without the need for hospitalization. We used the instrument entitled Surveillance of Violence and Accidents (VIVA) in sentinel urgency and emergency care services 7 . Only $9.6 \%$ of all cases involving external causes were admitted to hospital, according to VIVA-2009 7. This suggests that using data on hospitalizations from the SIH/SUS database computes only one out of ten cases of external causes that require medical care, that is, by calculating YLD without considering cases of emergency care, only $10 \%$ of all cases are tabulated.

Data from VIVA-2009 7 were thus used to estimate inflation factors for emergency care in relation to hospitalization from external causes, through logistic regression models. The models were adjusted to allow calculating inflation factors (according to the inverse of the predicted proportion of hospitalizations from a specific external cause). A model was adjusted for each of the most frequent external causes, namely: "road traffic accidents", falls, burns, assault, "other causes", and "all causes". The response variable used in the model was "hospitalization" (yes or no). The model included the following explanatory variables: geographic region of residence, gender, age bracket, and five categories of injuries available in VIVA-2009 7. For goodness of fit, we calculated the overall proportion of correct classifications for each model. This value varied from $77.1 \%$ (model for "IIIA03 - falls") to $56.6 \%$ (model for "IIIB02 - homicide and violence") 8. The causes with the highest inflation factor are considered less serious, generating a large number of treatments and fewer hospital admissions than the other causes. These results are shown in detail in the manual for strategies to estimate external causes in Global Burden of Disease-Brazil $2008^{8}$.

The inflation factors for emergency treatments according to the regression model in the current study were based on only five categories of injuries, as available in VIVA-2009 7. The international methodology for estimating the burden of external causes is based on 32 categories of injuries, so a correction was necessary. The strategy we adopted was to generate an intermediate factor combining the regression models obtained in the current study with those developed by Mathers et al. 9 in an Australian study that follows the international parameters.

Both the deaths and hospitalizations whose diagnoses belonged to the group of events of undetermined intent (Y10-Y34), which the Global Burden of Disease study refers to as garbage codes, were redistributed proportionally by State of Brazil, gender, age bracket, and 32 categories of injuries from the classification used by Murray \& Lopez ${ }^{3}$.

A 3\% discount rate was used, and no weighting factor was used for age.

As for ethical issues, all the databases were obtained for the years 2007 to 2009 directly from the website of the Information Technology Department of the Unified National Health System (DATASUS), except for VIVA-2009, provided by the Department for Health Situation Analysis of the Brazilian Ministry of Health, after a term of concession and confidentiality was signed by the coordinator of the Global Burden of Disease Project, with subsequent approval by the Institutional Review Board of the Sergio Arouca National School of Public Health - ENSP/Fiocruz (CAAE: 0054.0.031.000-11).

\section{Results}

In 2008, there were an estimated 195 DALYs per 100 thousand inhabitants in Brazil from all causes. Of this total, 19 were specific to injuries from external causes, representing $10 \%$ of the country's total estimated burden of disease. We now present the results separately for YLLs, YLDs, and DALYs, stratified by geographic region, gender, and age bracket.

\section{Analysis by geographic region}

In Brazil, for both sexes and all age brackets, injuries from unintentional causes represent a slightly higher proportion than those from intentional causes among all DALYs from external causes (53.8\% and $46.2 \%$, respectively). However, the category homicide and violence had by far the largest share of years of life lost, accounting for $38.8 \%$ of the total burden of disease related to injuries from external causes. Road traffic accidents were the second leading cause, 
with $29.1 \%$ of the total, followed by other unintentional causes $(9.5 \%)$ and falls $(8.3 \%)$ (Table 1; Figure 1).

There was no important variation in the distribution of DALYs among the country's different regions, with 18 DALYs per 100 thousand inhabitants in the Southeast and 21 DALYs per 100 thousand in the Central West. In the North and Northeast, intentional injuries showed the largest share of all DALYs from external causes, comprising $50.2 \%$ and $52.8 \%$, respectively, of all years of life lost due to external causes. The opposite pattern was seen in the South (42\%) and Southeast $(42.7 \%)$. The categories "homicide and violence" and "road traffic accidents" were the two leading causes of DALYs in all regions of Brazil. The former group was particularly evident in the North and Northeast, where violence accounted for $43.9 \%$ and $46.6 \%$ of DALYs. In the South, Central West, and Southeast, road traffic accidents accounted respectively for $30.1 \%, 32.8 \%$, and $32.7 \%$ of all DALYs for this group. Interestingly, DALYs from falls appeared most in the Southeast (11.7\%) and South (9.2\%). DALYs from drowning were also important, especially in the North and Northeast, with $6.7 \%$ and $5.8 \%$ of the total, respectively (Table 1).

As with DALYs, the distribution of YLLs (mortality component) showed no major regional variation, ranging from 15 per 100 thousand inhabitants in the Southeast to 19 in the Central West. Considering all groups of external causes, YLLs accounted for the largest share of DALYs (88.3\%), except for injuries from falls, in which YLDs (morbidity component) was the greatest (52.3\%), as shown in Figure 1 .

Thus, as expected, YLLs followed the same pattern identified for DALYs, with mainly intentional external causes $(51.7 \%)$, in which "homicide and violence" showed the largest share (43.4\%). Road traffic accidents (31.2\%) and suicide and self-inflicted injuries $(7.8 \%)$ were the second and third leading external causes of YLLs (Table 2). Meanwhile, YLDs involved mainly unintentional external causes (95.4\%), in which other unintentional causes were the most common group $(37.8 \%)$, especially in the North $(59.9 \%)$ and Northeast (54.6\%). The exception was in the South and Southeast, where falls were the leading external cause, with $41.3 \%$ and $44.4 \%$ of YLDs, respectively (Table 3 ).

\section{Analysis by gender}

There was an important variation in the distribution of DALYs between genders. Men showed five times more DALYs than women (31 and 6 per 100 thousand, respectively).
In men, unintentional and intentional causes showed equal shares of all DALYs in Brazil, with homicide and violence (43\%) and road traffic accidents $(28.3 \%)$ as the leading external causes. This basic distribution was maintained after stratifying by geographic region, while in the Northeast homicide and violence accounted for more than half of all DALYs in men (51\%) (Table 1). When ranking the categories, YLLs showed the same pattern as for DALYs, as expected (Table 2). However, in the breakdown of YLDs, falls (36.3\%) were the most common cause, followed by other unintentional causes (35.9\%) (Table 3).

In women, the largest share of DALYs in Brazil involved unintentional causes (72.2\%), and as opposed to men, road traffic accidents $(31.2 \%)$ and homicide and violence (18.9\%) were the two leading external causes of DALYs, in that order. However, this pattern varied between geographic regions. The amount of DALYs related to falls exceeded that for "homicide and violence" in the South and Southeast, accounting for $16.1 \%$ and $20.3 \%$ of all DALYs, respectively (Table 1). As seen in men, YLLs in women also followed the distribution of DALYs (Table 2). The leading causes of YLDs were other unintentional causes (35.9\%) and falls (39\%) (Table 3).

\section{Analysis by age bracket}

As for age distribution of DALYs from external causes, the largest bracket was 15-29 years, with $44.4 \%$ of years of life lost, followed by the 30-44-year bracket, with $26.8 \%$ (Figure 2). This pattern appeared in both intentional and unintentional causes. Interestingly, however, there was a high concentration of years of life lost in the group of intentional causes in the 15-44-year bracket, including $86 \%$ of DALYs from intentional causes as compared to $59 \%$ from unintentional causes (Figures 3 and 4).

Stratification by gender in the age group showed a higher share of men in all age brackets, especially for intentional causes in men 15 to 29 years of age. Meanwhile, there was a higher share of women in the under-15 and 60-and-over age brackets (Figures 3 and 4 )

Considering all age brackets, DALYs from unintentional injuries accounted for ten times more YLDs when compared to intentional injuries ( $20 \%$ and $2 \%$, respectively). For both groups of causes, YLDs were higher in the under-15 and 60 -and-over age brackets (Figures 1 and 2). 
Table 1

Distribution of DALYs (disability-adjusted life years) from external causes according to gender and geographic region.

Brazil, 2008.

\begin{tabular}{|c|c|c|c|c|c|c|}
\hline External causes & $\begin{array}{c}\text { North } \\
\%\end{array}$ & $\begin{array}{c}\text { Northeast } \\
\%\end{array}$ & $\begin{array}{c}\text { Southeast } \\
\%\end{array}$ & $\begin{array}{c}\text { South } \\
\%\end{array}$ & $\begin{array}{c}\text { Central West } \\
\%\end{array}$ & $\begin{array}{c}\text { Brazil } \\
\%\end{array}$ \\
\hline \multicolumn{7}{|l|}{ Men } \\
\hline III DALYs per 100,000 inhabitants (n) & 3,064 & 3,257 & 2,961 & 3,195 & 3,576 & 3,131 \\
\hline III (\%) & 100.0 & 100.0 & 100.0 & 100.0 & 100.0 & 100.0 \\
\hline IIIA01 road traffic accidents & 23.9 & 25.0 & 30.1 & 32.7 & 31.7 & 28.6 \\
\hline IIIA02 accidental poisoning & 0.4 & 0.2 & 0.3 & 0.3 & 0.4 & 0.3 \\
\hline IIIA03 falls & 4.6 & 3.5 & 9.7 & 7.6 & 5.8 & 6.9 \\
\hline IIIA04 burns and frostbite & 0.5 & 0.7 & 1.1 & 1.3 & 0.8 & 0.9 \\
\hline IIIA05 drowning & 6.3 & 5.7 & 4.0 & 4.1 & 4.0 & 4.7 \\
\hline IIIA06 other unintentional causes & 9.9 & 7.9 & 7.6 & 8.2 & 8.8 & 8.1 \\
\hline IIIA07 complications of medical care & 0.2 & 0.4 & 0.8 & 0.3 & 0.3 & 0.5 \\
\hline IIIB01 suicide and self-inflicted injuries & 6.0 & 5.5 & 6.2 & 9.7 & 6.8 & 6.5 \\
\hline IIIB02 homicide and violence & 48.3 & 51.0 & 39.2 & 35.5 & 41.4 & 43.0 \\
\hline IIIB03 legal intervention and war & 0.03 & 0.1 & 1.1 & 0.2 & 0.1 & 0.5 \\
\hline Total unintentional (sum of IIIA) & 45.7 & 43.4 & 53.6 & 54.6 & 51.7 & 50.0 \\
\hline Total intentional (sum of IIIB) & 54.3 & 56.6 & 46.4 & 45.4 & 48.3 & 50.0 \\
\hline \multicolumn{7}{|l|}{ Women } \\
\hline III DALYs per 100,000 inhabitants (n) & 596 & 546 & 634 & 717 & 752 & 626 \\
\hline III (\%) & 100.0 & 100.0 & 100.0 & 100.0 & 100.0 & 100.0 \\
\hline IIIA01 road traffic accidents & 31.4 & 29.0 & 30.2 & 33.4 & 37.5 & 31.2 \\
\hline IIIA02 accidental poisoning & 0.9 & 0.6 & 0.6 & 0.6 & 0.5 & 0.6 \\
\hline IIIA03 falls & 8.3 & 9.3 & 20.3 & 16.1 & 11.2 & 15.3 \\
\hline IIIA04 burns and frostbite & 1.5 & 2.3 & 2.5 & 2.6 & 1.6 & 2.3 \\
\hline IIIA05 drowning & 8.6 & 6.0 & 2.7 & 2.8 & 3.2 & 4.0 \\
\hline IIIA06 other unintentional causes & 20.3 & 19.7 & 14.4 & 16.4 & 16.5 & 16.6 \\
\hline IIIA07 complications of medical care & 0.6 & 2.2 & 3.0 & 1.2 & 1.6 & 2.2 \\
\hline IIIB01 suicide and self-inflicted injuries & 7.6 & 9.2 & 8.4 & 10.8 & 8.6 & 8.9 \\
\hline IIIB02 homicide and violence & 20.8 & 21.7 & 17.9 & 16.0 & 19.4 & 18.9 \\
\hline IIIB03 legal intervention and war & 0.1 & 0.0 & 0.0 & 0.0 & 0.0 & 0.0 \\
\hline Total unintentional (sum of IIIA) & 71.5 & 69.1 & 73.7 & 73.1 & 72.1 & 72.2 \\
\hline Total intentional (sum of IIIB) & 28.5 & 30.9 & 26.3 & 26.9 & 27.9 & 27.8 \\
\hline \multicolumn{7}{|l|}{ Both sexes } \\
\hline III(n) DALYs per 100,000 inhabitants (n) & 1,846 & 1,877 & 1,769 & 1,939 & 2,151 & 1,857 \\
\hline$\| 11(\%)$ & 100.0 & 100.0 & 100.0 & 100.0 & 100.0 & 100.0 \\
\hline IIIA01 road traffic accidents & 25.1 & 25.6 & 30.1 & 32.8 & 32.7 & 29.1 \\
\hline IIIA02 accidental poisoning & 0.4 & 0.3 & 0.3 & 0.3 & 0.4 & 0.3 \\
\hline IIIA03 falls & 5.2 & 4.4 & 11.7 & 9.2 & 6.8 & 8.3 \\
\hline IIIA04 burns and frostbite & 0.6 & 0.9 & 1.3 & 1.6 & 0.9 & 1.2 \\
\hline IIIA05 drowning & 6.7 & 5.8 & 3.8 & 3.9 & 3.9 & 4.6 \\
\hline IIIA06 other unintentional causes & 11.5 & 9.6 & 8.9 & 9.7 & 10.1 & 9.5 \\
\hline IIIA07 complications of medical care & 0.2 & 0.7 & 1.2 & 0.5 & 0.5 & 0.8 \\
\hline IIIB01 suicide and self-inflicted injuries & 6.2 & 6.0 & 6.6 & 9.9 & 7.1 & 6.9 \\
\hline IIIB02 homicide and violence & 43.9 & 46.6 & 35.3 & 31.9 & 37.5 & 38.8 \\
\hline IIIB03 legal intervention and war & 0.0 & 0.1 & 0.9 & 0.1 & 0.1 & 0.4 \\
\hline Total unintentional (sum of IIIA) & 49.8 & 47.2 & 57.3 & 58.0 & 55.3 & 53.8 \\
\hline Total intentional (sum of IIIB) & 50.2 & 52.8 & 42.7 & 42.0 & 44.7 & 46.2 \\
\hline
\end{tabular}


Figure 1

Distribution of YLLs, YLDs, and gender according to groups of external causes. Brazil, 2008.

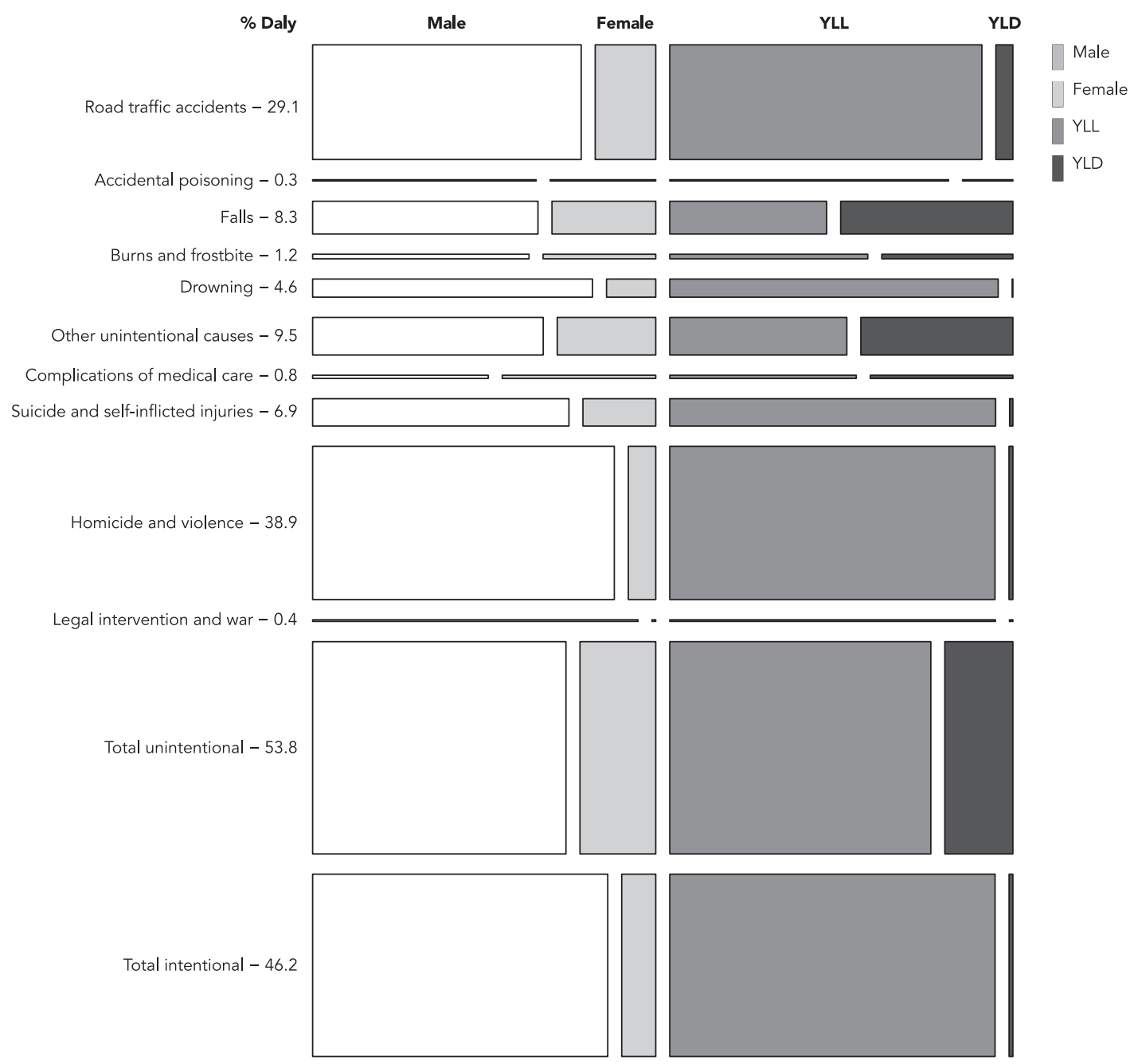

DALYs: disability-adjusted life years; YLDs: years lived with disability; YLLs: years of life lost.

\section{Discussion}

\section{Summary of findings}

In Brazil, injuries from external causes in 2008 accounted for some $10 \%$ of the estimated global burden of disease. The sex ratio (male-to-female) was 4.8 for DALYs, with a higher predominance of unintentional causes in women and 15-29 years as the predominant age bracket. For YLLs, the proportions of unintentional causes (48\%) and intentional causes (52\%) were balanced. For YLDs, unintentional causes predominated, with 95\%. The share of YLLs in DALYs was 90\%. The cause with the highest proportion of YLLs was homicide and violence $(43.4 \%)$, followed by road traffic accidents $(31.2 \%)$. Falls showed the highest share of YLDs (36.3\%).

There was no significant variation in the distribution of DALYs in the different regions of the country, but there was a difference in the ranking of causes. The South and Southeast had the highest shares of falls and road traffic accidents, while the North and Northeast lost more years due to homicide and violence. 
Table 2

Distribution of YLLs (years of life lost) from external causes according to gender and geographic region. Brazil, 2008.

\begin{tabular}{|c|c|c|c|c|c|c|}
\hline External causes & $\begin{array}{c}\text { North } \\
\%\end{array}$ & $\begin{array}{c}\text { Northeast } \\
\%\end{array}$ & $\begin{array}{c}\text { Southeast } \\
\%\end{array}$ & $\begin{array}{c}\text { South } \\
\%\end{array}$ & $\begin{array}{c}\text { Central West } \\
\%\end{array}$ & $\begin{array}{c}\text { Brazil } \\
\%\end{array}$ \\
\hline \multicolumn{7}{|l|}{ Men } \\
\hline $\begin{array}{l}\text { III YLLs per 100,000 } \\
\text { inhabitants (n) }\end{array}$ & 2,819 & 3,060 & 2,633 & 2,868 & 3,268 & 2,848 \\
\hline III (\%) & 100.0 & 100.0 & 100.0 & 100.0 & 100.0 & 100.0 \\
\hline IIIA01 road traffic accidents & 25.4 & 25.6 & 31.5 & 35.3 & 33.7 & 30.0 \\
\hline IIIA02 accidental poisoning & 0.2 & 0.2 & 0.3 & 0.2 & 0.4 & 0.3 \\
\hline IIIA03 falls & 2.7 & 2.3 & 5.6 & 3.7 & 3.5 & 3.9 \\
\hline IIIA04 burns and frostbite & 0.4 & 0.5 & 0.7 & 0.9 & 0.6 & 0.6 \\
\hline IIIA05 drowning & 6.9 & 6.1 & 4.5 & 4.6 & 4.4 & 5.2 \\
\hline $\begin{array}{l}\text { IIIA06 other unintentional } \\
\text { causes }\end{array}$ & 5.8 & 5.1 & 5.5 & 4.9 & 5.3 & 5.3 \\
\hline $\begin{array}{l}\text { IIIA07 complications of } \\
\text { medical care }\end{array}$ & 0.2 & 0.3 & 0.3 & 0.1 & 0.2 & 0.3 \\
\hline $\begin{array}{l}\text { IIIB01 suicide and self-inflicted } \\
\text { injuries }\end{array}$ & 6.3 & 5.8 & 6.9 & 10.8 & 7.4 & 7.1 \\
\hline IIIB02 homicide and violence & 52.1 & 54.0 & 43.4 & 39.3 & 44.5 & 46.8 \\
\hline $\begin{array}{l}\text { IIIB03 legal intervention and } \\
\text { war }\end{array}$ & 0.0 & 0.1 & 1.2 & 0.2 & 0.1 & 0.6 \\
\hline Total unintentional (sum of IIIA) & 41.5 & 40.1 & 48.4 & 49.8 & 48.0 & 45.5 \\
\hline Total intentional (sum of IIIB) & 58.5 & 59.9 & 51.6 & 50.2 & 52.0 & 54.5 \\
\hline \multicolumn{7}{|l|}{ Women } \\
\hline $\begin{array}{l}\text { III YLLs per 100,000 } \\
\text { inhabitants (n) }\end{array}$ & 457 & 435 & 463 & 533 & 599 & 475 \\
\hline III (\%) & 100.0 & 100.0 & 100.0 & 100.0 & 100.0 & 100.0 \\
\hline IIIA01 road traffic accidents & 39.2 & 34.3 & 37.4 & 42.6 & 45.3 & 38.3 \\
\hline IIIA02 accidental poisoning & 0.8 & 0.6 & 0.7 & 0.6 & 0.6 & 0.7 \\
\hline IIIA03 falls & 4.2 & 5.6 & 10.0 & 7.3 & 6.1 & 7.7 \\
\hline IIIA04 burns and frostbite & 1.5 & 2.0 & 1.8 & 1.7 & 1.4 & 1.8 \\
\hline IIIA05 drowning & 11.2 & 7.5 & 3.7 & 3.7 & 4.0 & 5.3 \\
\hline $\begin{array}{l}\text { IIIA06 other unintentional } \\
\text { causes }\end{array}$ & 6.5 & 9.4 & 9.6 & 7.8 & 6.9 & 8.8 \\
\hline $\begin{array}{l}\text { IIIA07 complications of } \\
\text { medical care }\end{array}$ & 0.7 & 2.4 & 2.3 & 1.0 & 1.2 & 1.9 \\
\hline $\begin{array}{l}\text { IIIB01 suicide and self-inflicted } \\
\text { injuries }\end{array}$ & 9.5 & 11.5 & 11.2 & 14.3 & 10.7 & 11.6 \\
\hline IIIB02 homicide and violence & 26.3 & 26.7 & 23.4 & 20.9 & 23.9 & 24.1 \\
\hline $\begin{array}{l}\text { IIIB03 legal intervention } \\
\text { and war }\end{array}$ & 0.1 & 0.0 & 0.0 & 0.0 & 0.0 & 0.0 \\
\hline Total unintentional (sum of IIIA) & 64.1 & 61.9 & 65.4 & 64.8 & 65.4 & 64.3 \\
\hline Total intentional (sum of IIIB) & 35.9 & 38.1 & 34.6 & 35.2 & 34.6 & 35.7 \\
\hline
\end{tabular}

(continues) 


\begin{tabular}{|c|c|c|c|c|c|c|}
\hline External causes & $\begin{array}{c}\text { North } \\
\%\end{array}$ & $\begin{array}{c}\text { Northeast } \\
\%\end{array}$ & $\begin{array}{c}\text { Southeast } \\
\%\end{array}$ & $\begin{array}{c}\text { South } \\
\%\end{array}$ & $\begin{array}{c}\text { Central West } \\
\%\end{array}$ & $\begin{array}{c}\text { Brazil } \\
\%\end{array}$ \\
\hline \multicolumn{7}{|l|}{ Both sexes } \\
\hline III YLLs per 100,000 & 1,652 & 1,724 & 1,521 & 1,684 & 1,922 & 1,641 \\
\hline \multicolumn{7}{|l|}{ inhabitants (n) } \\
\hline III (\%) & 100.0 & 100.0 & 100.0 & 100.0 & 100.0 & 100.0 \\
\hline IIIA01 road traffic accidents & 27.3 & 26.7 & 32.4 & 36.5 & 35.5 & 31.2 \\
\hline IIIA02 accidental poisoning & 0.3 & 0.3 & 0.3 & 0.3 & 0.4 & 0.3 \\
\hline IIIA03 falls & 2.9 & 2.7 & 6.3 & 4.3 & 3.9 & 4.5 \\
\hline IIIA04 burns and frostbite & 0.5 & 0.7 & 0.8 & 1.0 & 0.7 & 0.8 \\
\hline IIIA05 drowning & 7.5 & 6.3 & 4.4 & 4.4 & 4.3 & 5.2 \\
\hline $\begin{array}{l}\text { IIIA06 other unintentional } \\
\text { causes }\end{array}$ & 5.9 & 5.6 & 6.1 & 5.3 & 5.6 & 5.8 \\
\hline $\begin{array}{l}\text { IIIA07 complications of } \\
\text { medical care }\end{array}$ & 0.2 & 0.6 & 0.6 & 0.3 & 0.4 & 0.5 \\
\hline $\begin{array}{l}\text { IIIB01 suicide and self-inflicted } \\
\text { injuries }\end{array}$ & 6.7 & 6.5 & 7.6 & 11.3 & 7.9 & 7.8 \\
\hline IIIB02 homicide and violence & 48.6 & 50.4 & 40.3 & 36.3 & 41.2 & 43.4 \\
\hline $\begin{array}{l}\text { IIIB03 legal intervention and } \\
\text { war }\end{array}$ & 0.0 & 0.1 & 1.0 & 0.1 & 0.1 & 0.5 \\
\hline Total unintentional (sum of IIIA) & 44.6 & 42.9 & 51.1 & 52.2 & 50.7 & 48.3 \\
\hline Total intentional (sum of IIIB) & 55.4 & 57.1 & 48.9 & 47.8 & 49.3 & 51.7 \\
\hline
\end{tabular}

\section{Results in the context of previous international research}

Injuries from external causes accounted for $11 \%$ of the estimated global burden of disease for the year 201010 , consistent with the current study's findings (10\%).

In Brazil, homicide and violence were the leading causes of years of life lost to external causes in 2008 (38.8\%), especially in the North (43.9\%) and Northeast (46.6\%). This pattern differs from international studies, which in 2010 showed these causes in fourth place among DALY from external causes (9.2\%), following road traffic accidents $(27.3 \%)$, suicide $(13.3 \%)$, and falls $(12.8 \%) 10$. The large number of homicides in North and Northeast Brazil is a recent phenomenon. From 2000 and 2010, the homicide rates in the two regions increased respectively from 34.2 and 34 to 45.8 and 55.7 per 100 thousand inhabitants, an increase of $33.6 \%$ and $64 \%$. Meanwhile, the opposite pattern was seen in the Southeast region, where the homicide rate dropped from 58.9 to 19.9 per 100 thousand inhabitants, a decrease of $66 \% 11$. Among the factors that may have contributed to this reversal, Waiselfisz 11 highlights the following: (1) the emergence of economic hubs unaccompanied by adequate public security policies, thereby facilitating a rise in crime; (2) the national public security policy in 1999 and the national security fund established in January 2001, which ensured the transfer of funds to equip law enforcement in the State capitals and metropolitan areas; and (3) the decrease in underreporting in various regions of the country. However, despite the undeniable decreases in homicide rates in the Southeast, the current study showed that homicides still represented the largest share of DALYs from external causes. In addition, in all regions of Brazil, the crude DALY rates from homicides and violence were extremely high, well above those in the world as a whole 10 .

In the current study, road traffic accidents ranked second among DALYs from external causes, considering both sexes and all age brackets in all regions of the country, while ranking first in the South. For the world as a whole, road traffic accidents led the list of external causes in 2010 (27.3\%) 9. The World Health Organization estimates that 1.24 million persons die from road traffic accidents per year, as the leading cause of death among young people 15 to 29 years of age 11. Road traffic accidents hit poor countries the hardest. While the world mortality rate from road traffic accidents is 18 per 100 thousand inhabitants, the figure increases to 20.1 in medium-income countries and drops to 8.7 in high-income 
Distribution of YLDs (years lived with disability) from external causes according to gender and geographic region. Brazil, 2008.

\begin{tabular}{|c|c|c|c|c|c|c|}
\hline External causes & $\begin{array}{c}\text { North } \\
\%\end{array}$ & $\begin{array}{c}\text { Northeast } \\
\%\end{array}$ & $\begin{array}{c}\text { Southeast } \\
\%\end{array}$ & $\begin{array}{c}\text { South } \\
\%\end{array}$ & $\begin{array}{c}\text { Central West } \\
\%\end{array}$ & $\begin{array}{c}\text { Brazil } \\
\%\end{array}$ \\
\hline \multicolumn{7}{|l|}{ Men } \\
\hline III YLDs per 100,000 inhabitants (n) & 246 & 197 & 328 & 329 & 307 & 283 \\
\hline III (\%) & 100.0 & 100.0 & 100.0 & 100.0 & 100.0 & 100.0 \\
\hline IIIA01 road traffic accidents & 6.8 & 15.2 & 18.8 & 9.8 & 10.7 & 15.1 \\
\hline IIIA02 accidental poisoning & 1.7 & 0.3 & 0.2 & 0.6 & 0.3 & 0.4 \\
\hline IIIA03 falls & 26.7 & 23.3 & 42.3 & 41.1 & 30.9 & 36.3 \\
\hline IIIA04 burns and frostbite & 1.6 & 3.1 & 4.2 & 5.3 & 3.3 & 3.9 \\
\hline IIIA05 drowning & 0.0 & 0.2 & 0.1 & 0.0 & 0.0 & 0.1 \\
\hline IIIA06 other unintentional causes & 56.6 & 51.4 & 24.6 & 37.5 & 45.4 & 35.9 \\
\hline IIIA07 complications of medical care & 0.3 & 1.5 & 4.6 & 1.9 & 0.9 & 2.9 \\
\hline IIIB01 suicide and self-inflicted injuries & 2.1 & 0.4 & 0.4 & 0.6 & 0.3 & 0.5 \\
\hline IIIB02 homicide and violence & 4.2 & 4.7 & 4.8 & 3.1 & 8.3 & 4.7 \\
\hline IIIB03 legal intervention and war & 0.0 & 0.0 & 0.0 & 0.1 & 0.0 & 0.0 \\
\hline Total unintentional (sum of IIIA) & 93.6 & 94.9 & 94.8 & 96.2 & 91.5 & 94.7 \\
\hline Total intentional (sum of IIIB) & 6.4 & 5.1 & 5.2 & 3.8 & 8.5 & 5.3 \\
\hline \multicolumn{7}{|l|}{ Women } \\
\hline III YLDs per 100,000 inhabitants (n) & 138 & 111 & 171 & 184 & 153 & 152 \\
\hline III (\%) & 100.0 & 100.0 & 100.0 & 100.0 & 100.0 & 100.0 \\
\hline IIIA01 road traffic accidents & 5.4 & 8.0 & 10.9 & 6.6 & 7.0 & 8.9 \\
\hline IIIA02 accidental poisoning & 1.2 & 0.3 & 0.4 & 0.6 & 0.3 & 0.5 \\
\hline IIIA03 falls & 22.1 & 23.6 & 48.2 & 41.7 & 31.0 & 39.0 \\
\hline IIIA04 burns and frostbite & 1.4 & 3.7 & 4.4 & 5.3 & 2.2 & 4.0 \\
\hline IIIA05 drowning & 0.0 & 0.2 & 0.0 & 0.1 & 0.0 & 0.1 \\
\hline IIIA06 other unintentional causes & 65.9 & 60.2 & 27.4 & 41.2 & 54.3 & 41.2 \\
\hline IIIA07 complications of medical care & 0.1 & 1.4 & 4.9 & 1.9 & 3.4 & 3.2 \\
\hline IIIB01 suicide and self-inflicted injuries & 1.4 & 0.2 & 0.9 & 0.7 & 0.2 & 0.7 \\
\hline IIIB02 homicide and violence & 2.5 & 2.3 & 2.9 & 1.9 & 1.4 & 2.5 \\
\hline IIIB03 legal intervention and war & 0.0 & 0.0 & 0.0 & 0.1 & 0.0 & 0.0 \\
\hline Total unintentional (sum of IIIA) & 96.0 & 97.5 & 96.2 & 97.3 & 98.3 & 96.8 \\
\hline Total intentional (sum of IIIB) & 4.0 & 2.5 & 3.8 & 2.7 & 1.7 & 3.2 \\
\hline \multicolumn{7}{|l|}{ Both sexes } \\
\hline III YLDs per 100,000 inhabitants (n) & 193 & 153 & 248 & 255 & 229 & 217 \\
\hline III (\%) & 100.0 & 100.0 & 100.0 & 100.0 & 100.0 & 100.0 \\
\hline IIIA01 road traffic accidents & 6.3 & 12.6 & 16.0 & 8.6 & 9.4 & 12.9 \\
\hline IIIA02 accidental poisoning & 1.5 & 0.3 & 0.3 & 0.6 & 0.3 & 0.4 \\
\hline IIIA03 falls & 25.0 & 23.4 & 44.4 & 41.3 & 30.9 & 37.3 \\
\hline IIIA04 burns and frostbite & 1.5 & 3.3 & 4.3 & 5.3 & 2.9 & 4.0 \\
\hline IIIA05 drowning & 0.0 & 0.2 & 0.1 & 0.0 & 0.0 & 0.1 \\
\hline IIIA06 other unintentional causes & 59.9 & 54.6 & 25.6 & 38.9 & 48.4 & 37.8 \\
\hline IIIA07 complications of medical care & 0.2 & 1.4 & 4.7 & 1.9 & 1.7 & 3.0 \\
\hline IIIB01 suicide and self-inflicted injuries & 1.9 & 0.3 & 0.5 & 0.7 & 0.3 & 0.6 \\
\hline IIIB02 homicide and violence & 3.6 & 3.8 & 4.1 & 2.7 & 6.0 & 3.9 \\
\hline IIIB03 legal intervention and war & 0.0 & 0.0 & 0.0 & 0.1 & 0.0 & 0.0 \\
\hline Total unintentional (sum of IIIA) & 94.5 & 95.9 & 95.3 & 96.6 & 93.8 & 95.4 \\
\hline Total intentional (sum of IIIB) & 5.5 & 4.1 & 4.7 & 3.4 & 6.2 & 4.6 \\
\hline
\end{tabular}


Figure 2

Distribution of YLLs, YLDs, and age brackets among groups of intentional and unintentional external causes. Brazil, 2008.
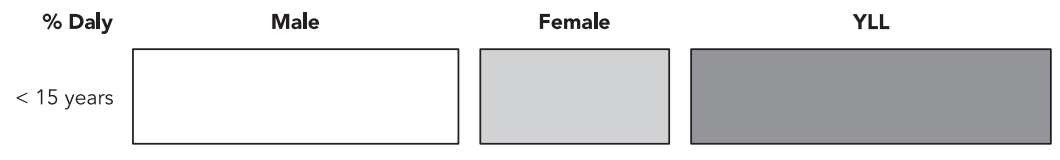

YLD
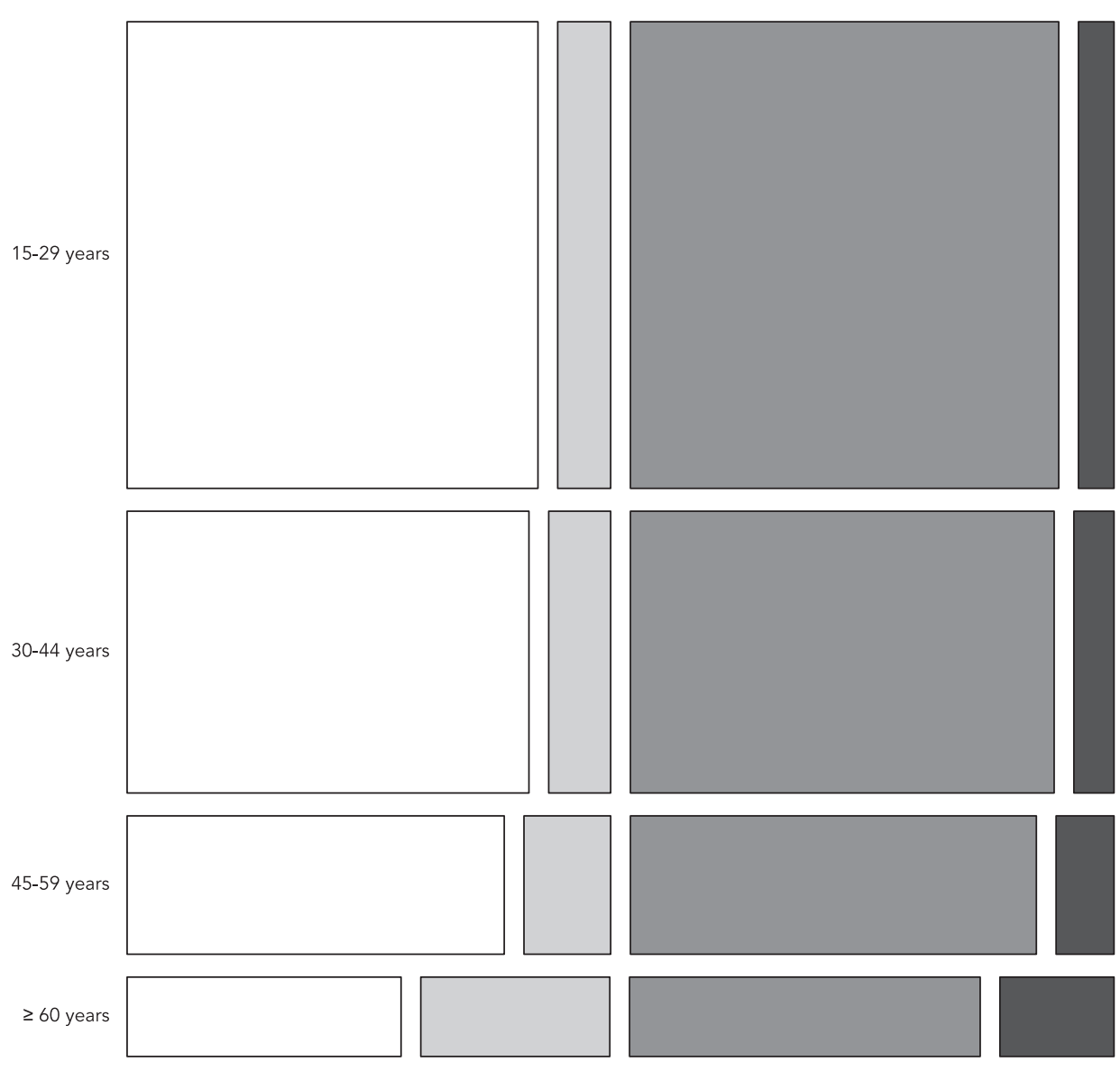

DALYs: disability-adjusted life years; YLDs: years lived with disability; YLLs: years of life lost.

countries 12 . In 2009 , only 28 countries had legislation that adequately regulated the five essential measures for preventing motor vehicle accidents, namely speed control, control of alcohol use by drivers, use of helmets by motorcyclists, use of seatbelts, and use of infant safety seats in automobiles 12. In 2010, the United Nations declared 2011-2020 as the Decade of Action for Road Safety ${ }^{13}$. The goal is to save five million lives during this period. The proposed action plan is divided into five main interventions: strengthening management, investment in roadway infrastructure, vehicle safety, traffic user behavior and safety, and pre-hospital and in-hospital trauma care 13. In Brazil, important measures to deal with this problem feature the enactment of the National Traffic Code in 199814 and the Lei Seca (or "Dry Law", enforcing stricter control on drinking and driving) 15 , which entered into force ten years later, in 2008, both aimed at decreasing hospitalizations and deaths 16. Despite these measures, a recent report 17 showed that morbidity and mortality from road traffic accidents have increased systematically since 1980 , fueled mainly by the increase in the country's motorcycle fleet. According to the same report, from 2001 and 2011, the mortality rates from these events decreased in all regions of Brazil except the Central West, 
Figure 3

Distribution of YLLs, YLDs, and gender according to age bracket among groups of intentional external causes. Brazil, 2008.

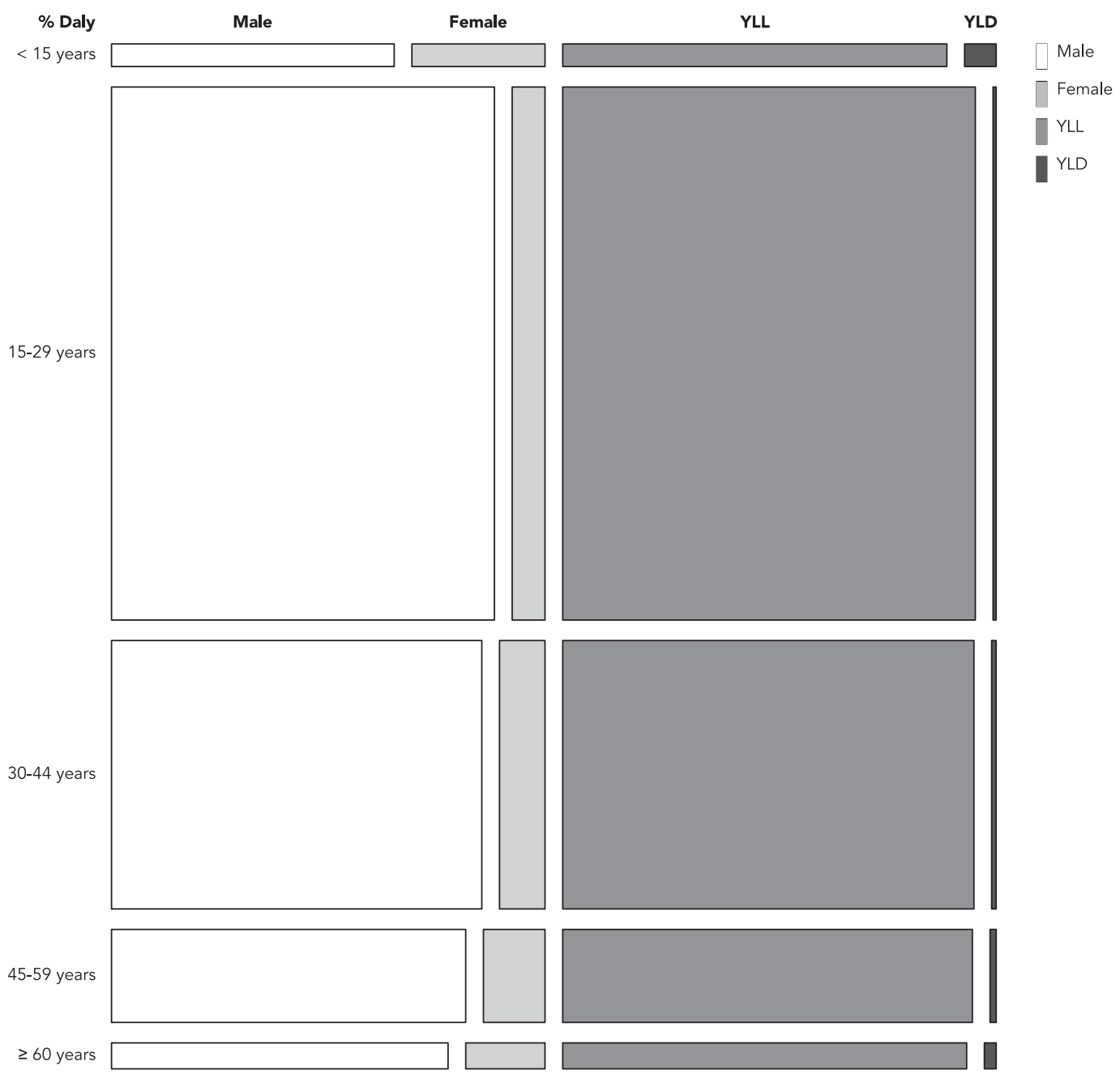

DALYs: disability-adjusted life years; YLDs: years lived with disability; YLLs: years of life lost.

North, and Northeast, where they increased by $2.9 \%, 14.3 \%$, and $21.1 \%$, respectively. In the current study, the North and Northeast were the regions with the lowest traffic accident rates, both as the proportion of external causes (25.1 and $25.6 \%$, respectively) and as crude DALY rates (463 and 480 DALYs per 100 thousand inhabitants, respectively), a situation that could change if the mortality rates continue to grow there.

In the current study, falls accounted for the fourth leading share of DALYs from external causes and the third among unintentional causes. Worldwide, falls are the second leading cause of death from unintentional injuries 1 .
Falls are the most common unintentional injury among children and the elderly. Agran et al. 18 found that falls were the main mechanism of trauma in children up to 3 years of age. For both children and the elderly, most falls occur at home 19. In Brazil, a cohort study of 1,667 elderly living in the city of São Paulo showed that $30 \%$ suffered falls at least once a year 20 . Factors associated with falls in the elderly include sedentary living, poor self-rated health, older age bracket, number of self-reported continuous-use medications, living at home, and income less than or equal to the minimum wage, among others 21,22 . The higher percentage of DALYs from falls in the South and 

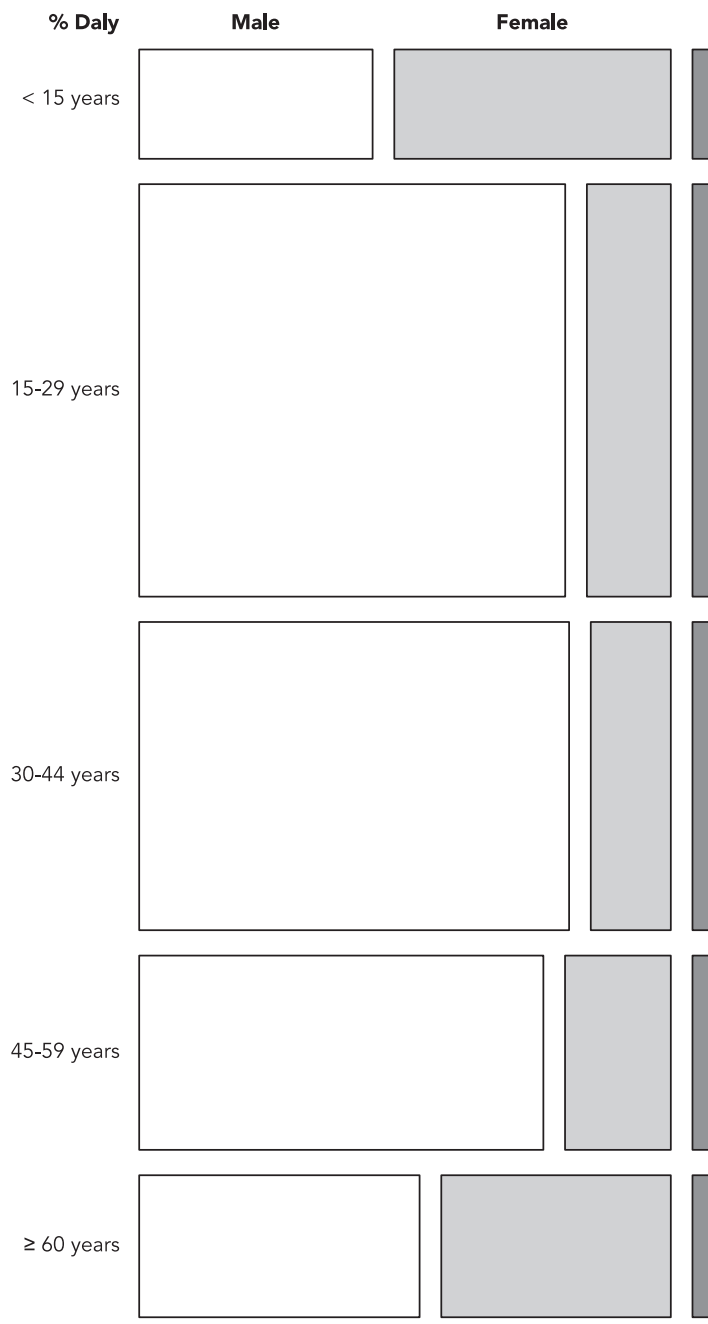

YLL
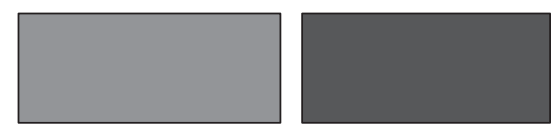

Male

Female

L YLL
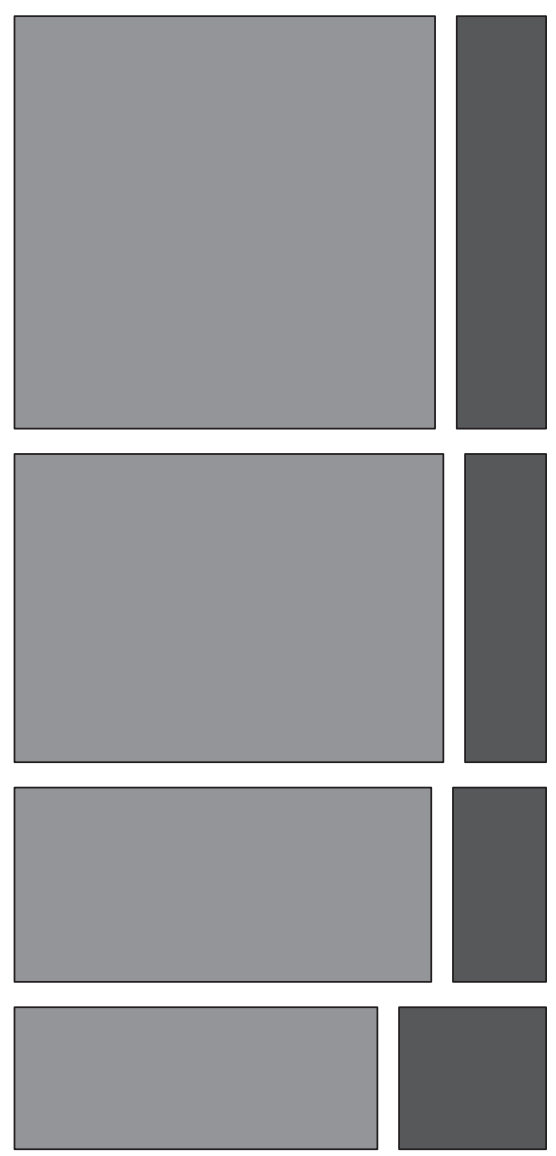

DALYs: disability-adjusted life years; YLDs: years lived with disability; YLLs: years of life lost.

Southeast of Brazil could be explained by the demographic profile of these two regions, with a higher concentration of elderly individuals 23 . The higher share of falls among women was also expected, since both life expectancy and prevalence of chronic illnesses are higher in females 24.

In Brazil, suicide did not play a major role in DALYs from external causes in 2008, ranking fifth, unlike the world as a whole where it ranked second from external causes (13.3\%) in 201010. In the South and Central West of Brazil, suicides were more prominent, both in terms of the crude rate (193 and 153 DALYs per 100 thousand in- habitants, respectively) and in the share of DALYs from external causes $(9.9 \%$ and $7.1 \%)$, according to the literature on mortality analysis 24 . However, the current study only disaggregated the analysis down to the regional level, thus preventing a more in-depth understanding of the phenomenon. Recent studies point to high suicide rates in certain Brazilian municipalities (counties), especially those with ethnic minorities such as indigenous communities 25,26 .

As for differences by gender, in all groups of external causes, men showed far higher crude DALY rates than women according to the Brazil- 
ian literature analyzing morbidity and mortality rates 26,27 . Studies indicate that the systematic rise in external causes in recent decades involved mainly men, while the mortality rates from these injuries have remained virtually stable in women since the 1980s 26,28 . There is well-known overmortality among men for all underlying causes and age groups in the external causes group, resulting in relatively higher life expectancy in women 27. In Brazil, an important proposal for dealing with this situation was the National Policy for Comprehensive Healthcare for Men 29, the aim of which is to upgrade healthcare for the male population, from the perspective of lines of comprehensive care. Briefly, the policy aims to favorably impact morbidity and mortality, increasing life expectancy and quality of life in the male population.

According to this study's findings, $71 \%$ of the total burden of disease related to injuries in Brazil affects individuals in the 15 to 44 -year age bracket. The proportion increases to $85 \%$ for intentional injuries. By mainly affecting working-age individuals, external causes take a heavy toll on family budgets. Aeron-Thomas et al. 30 even observed a drop in food consumption among family members of victims. In poorer countries like Vietnam, $90.0 \%$ of the expenses for treating injuries from external causes are born by the victims or their families, corresponding to seven months of work 31 . In Canada, injuries cost 19.8 billion dollars in 2004 , a year in which 13,667 persons died and more than 60 thousand were partially disabled from injuries. In the United States, medical expenditures related to injuries remained constant from 1985 to 2000 and were estimated at 117 billion dollars, accounting for $10.3 \%$ of all medical expenses in the country ${ }^{2}$. In São Paulo State, Brazil, Mesquita Filho \& Mello Jorge 33 analyzed hospitalizations in the Unified National Health System (SUS) in the year 2000 and found that although injuries from external causes accounted for fewer than $10 \%$ of all admissions and showed shorter mean length-of-stay when compared to natural causes, the cost of treating their sequelae was higher (both for medical expenses and cost of hospitalization per day), and that patients who died showed three times higher expenditures than those who were discharged.

Analysis of risk factors related to burden of disease in the Global Burden of Disease-2010 study shows that of all DALYs related to external causes worldwide, $11.5 \%$ are attributed to alcohol abuse, $8.5 \%$ to occupational risks, and $2.8 \%$ to intimate partner violence ${ }^{1}$. In Brazil, a study of victims of injuries treated at a university hospital in Minas Gerais State found that blood tests for alcohol were positive in $31.8 \%$ of cases, with the following breakdown by specific causes: physical assault $(57.1 \%)$, road traffic accidents (29.3\%), and falls (18.2\%) 34 . In the attempt to reduce years of life lost from external causes, various preventive strategies have proven efficient in different countries 35. The Brazilian Ministry of Health, through the National Policy to Reduce Morbidity and Mortality from Accidents and Violence 36 , assumed an official commitment to act to reduce lesions from external causes, through both the prevention of injuries and the treatment of sequelae. The policy's various developments feature the VIVA-2009 survey 7 , implemented in the National Health System in 2006 and which serves as one of the sources for calculating YLDs, as presented in this article.

\section{Strengths and limitations of the study}

DALY is an extremely useful indicator for analyzing the profile of injuries from external causes. The absolute numbers for morbidity and mortality available in the databases are incapable of correctly measuring the impact of such injuries for society. DALY aggregates information on mortality and morbidity, in the latter case considering data on hospitalizations, use of emergency services, and the severity of sequelae. DALY is thus capable of better demonstrating the profile of injuries from external causes within the demographic and epidemiological transition 37 . Thus, although injuries from external causes represented $12.6 \%$ of all deaths in Brazil in 2008, in terms of burden of disease these events covered $17 \%$ of the years of life lost during that same year. This discrepancy is also due to the fact that external causes mainly affect young individuals, taking a heavy toll on healthy years of life. Finally, considering differences in the construction of the methodology, it is an internationally comparable indicator.

However, the methodology for the construction of DALY presents some weaknesses, given the limitations of the available databases. When possible, indirect techniques were used to correct the data: (1) For example, there is no periodically fed national database on emergency medical care. This problem was solved by using data from the VIVA-2009 survey 7 on the search for emergency care. Still, these data do not have a nationwide scope, and only include data from Brazil's State capitals; (2) Data from the Hospital Information System of the Unified National Health System (SIH/SUS), used to estimate hospitalizations, do not include the private sector. It was thus necessary to use an SUS correction factor 8 , which needs to be improved, given the complexity of the range of hospital procedures; 
(3) The Mortality Information System is known to suffer from under-recording ${ }^{38}$. Even so, by consensus in the literature, no methods are used to correct this problem, which can underestimate the results 39 .

\section{Implications for practice and research}

Construction of the DALY indicator involves a process of estimating dynamic diseases and injuries, requiring that the strategies employed in its execution undergo constant improvement. Therefore, studies on global burden of disease 3,40 have been updated with recent publications on methodological refinements and updates of results 41,42 . Thus, time trend assessments of the profiles resulting from the parameters should be performed with caution.

From the perspective of incorporating new developments, we suggest investing in cost-effectiveness studies that evaluate the impact of different health interventions in light of the burden of disease profile. Another important possibility is the identification of risk factors that account for a significant share of the burden of disease from external causes. We further suggest studying the evolution of burden of disease based on the comparison of the studies from 1998 and 2008, updating the data from the former with the methodology used in the latter.

\section{Resumen}

El objetivo de este artículo es estimar la carga global de las causas externas en el año 2008 en Brasil. La metodología calcula el indicador DALY (años de vida potencialmente perdidos). El YLL (años potenciales de vida perdidos) fue calculado siguiendo el método propuesto por Murray \& López (1996). Sin embargo, para las YLD (años vividos con discapacidad) se han aplicado enfoques metodológicos teniendo en cuenta el contexto brasileño. El DALY fue de 195 por cada 100 mil habitantes, de ellos, 19 eran específicos de causas externas. El YLL estaba compuesto por un 48\% de las lesiones intencionales y un $52 \%$ de las no intencionales. En el $Y L D$, las lesiones no intencionales corresponden a 95\%. El YLL contribuye al $90 \%$ del DALY. En el YLL, las causas más frecuentes fueron homicidios y la violencia (43\%), seguida de accidentes de tráfico (31\%). Las caídas son la mayor proporción del YLD (36\%). Había una razón hombre, mujer de 4,8 en el DALY, y el grupo de edad predominante fue de 15 a 29 años. Las lesiones son prevenibles en general y estos resultados pueden contribuir a proporcionar información importante para los responsables políticos en los campos de la salud y la seguridad pública.

Costo de Enfermedad; Causas Externas; Homicidio; Accidentes

\section{Contributors}

M. R. Campos and V. R. von Doellinger contributed to the study's conceptualization and design, data analysis, and writing and revision of the article. L. V. P. Mendes collaborated in the data analysis and writing and revision of the article. M. F. S. Costa and T. G. Pimentel participated in assembling the database, elaboration of the article, and analysis of the results. J. M. A. Schramm contributed to the study design and writing and revision of the article.

\section{Acknowledgments}

The authors wish to thank the Department of Science and Technology of the Brazilian Ministry of Health for funding the study, the entire team of the Nucleus for Research on Applied Methods in Studies on Global Burden of Disease, especially the coordinators Dr. Iuri Costa Leite and Dr. Joaquim Valente, and the Ministry of Health, especially Dr. Deborah Carvalho Malta, Director of the Department of Health Situation Analysis, for providing access to the VIVA-Brasil database. 


\section{References}

1. Institute for Health Metrics and Evaluation. Global Burden of Diseases, Injuries, and Risk Factors Study 2010 (GBD 2010). http://www.healthmetricsandevaluation.org/gbd/visualizations/regional (accessed on 16/Oct/2013).

2. World Health Organization. Violence, injuries and disability. Biennial report 2008-2009. Geneva: World Health Organization Press; 2012.

3. Murray CJL, Lopez AD; Harvard School of Public Health; World Health Organization; World Bank The global burden of disease: a comprehensive assessment of mortality and disability from diseases, injuries, and risk factors in 1990 and projected to 2020. Cambridge: Harvard University Press; 1996.

4. World Health Organization. World report on violence and health. Geneva: World Health Organization; 2002.

5. Rede Interagencial de Informações para a Saúde. Ficha de qualificação da cobertura de planos de saúde. http://www.ripsa.org.br/fichasIDB/record. php?node=f.15\&lang=pt\&version=ed6 (accessed on $25 /$ Oct $/ 2013$ )

6. Deslandes SF, Silva CMFP. Análise da morbidade hospitalar por acidentes de trânsito em hospitais públicos do Rio de Janeiro, RJ, Brasil. Rev Saúde Pública 2000; 34:367-72.

7. Departamento de Vigilância de Doenças e Agravos Não Transmissíveis e Promoção da Saúde, Secretaria de Vigilância em Saúde, Ministério da Saúde. Sistema de Vigilância de Violências e Acidentes (Viva): 2009, 2010 e 2011. Brasília: Ministério da Saúde; 2010.

8. Doerllinger VR, Campos MR. Diário de bordo da estimação das causas externas 2013. http://cargadedoenca.fiocruz.br (accessed on 25/Oct/2013).

9. Mathers C, Vos T, Stevenson C. The burden of disease and injury in Australia - summary report. Canberra: Australian Institute of Health and Welfare; 1999

10. Murray CJ, Vos T, Lozano R, Naghavi M, Flaxman AD, Michaud C, et al. Disability-adjusted life years (DALYs) for 291 diseases and injuries in 21 regions, 1990-2010: a systematic analysis for the Global Burden of Disease Study 2010. Lancet 2013; 380:2197-223.

11. Waiselfisz JJ. Mapa da violência 2013: homicídios e juventude no Brasil. http://observatorio.c3sl.ufpr. br/xmlui/handle/123456789/229 (accessed on 22/ Apr/2014).

12. World Health Organization. Global status report on road safety. Geneva: Word Health Organization Press; 2013.

13. World Health Organization. Global plan for the decade of action for road safety, 2011-2020. Geneva: World Health Organization Press; 2010.

14. Brasil. Lei no 9.503, de 23 de setembro de 1997. Institui o Código de Trânsito Brasileiro. Diário Oficial da União 1997; 24 set.
15. Brasil. Lei no 11.705 , de 19 de junho de 2008. Altera a Lei no 9.503, de 23 de setembro de 1997, que 'institui o Código de Trânsito Brasileiro', e a Lei no9.294, de 15 de julho de 1996, que dispõe sobre as restrições ao uso e à propaganda de produtos fumígeros, bebidas alcoólicas, medicamentos, terapias e defensivos agrícolas, nos termos do $\$ 4$ 으 do art. 220 da Constituição Federal, para inibir o consumo de bebida alcoólica por condutor de veículo automotor, e dá outras providências. Diário Oficial da União 2008; 20 jun.

16. Morais Neto OL, Montenegro MMS, Monteiro RA, Siqueira Júnior JBS, Silva MMA, Lima CM, et al. Mortalidade por acidentes de transporte terrestre no Brasil na última década: tendência e aglomerados de risco. Ciênc Saúde Coletiva 2012; 17:222336.

17. Waiselfisz JJ. Mapa da violência 2013: acidentes de trânsito e motocicletas. http://observatorio.c3sl. ufpr.br/xmlui/handle/123456789/229 (accessed on 22/Apr/2014).

18. Agran PF, Anderson C, Winn D, Trent R, WaltonHaynes L, Thayer S. Rates of pediatric injuries by 3 -month intervals for children 0 to 3 years of age. Pediatrics 2003; 111:e683-92.

19. Paes CEN, Gaspar VLV. As lesões não intencionais no ambiente domiciliar: a casa segura. J Pediatr (Rio J.) 2005; 81 Suppl 5:S146-54.

20. Couto FBD, Perracini MR. Multifactorial profile analysis of active older adults with history of falls. Rev Bras Geriatr E Gerontol 2012; 15:693-706.

21. Almeida ST, Soldera CLC, Carli GA, Gomes I, Resende TL. Análise de fatores extrínsecos e intrínsecos que predispõem a quedas em idosos; Analysis of extrinsic and intrinsic factors that predispose elderly individuals to fall. Rev Assoc Med Bras (1992) 2012; 58:427-33.

22. Siqueira FV, Facchini LA, Piccini RX, Tomasi E, Thumé E, Silveira DS, et al. Prevalência de quedas em idosos e fatores associados. Rev Saúde Pública 2007; 41:749-56.

23. Aguiar CF, Assis M. Perfil de mulheres idosas segundo a ocorrência de quedas: estudo de demanda no Núcleo de Atenção ao Idoso da UnATI/UERJ. Rev Bras Geriatr Gerontol 2009; 12:391-404.

24. Brzozowski FS, Soares GB, Benedet J, Boing AF, Peres MA. Suicide time trends in Brazil from 1980 to 2005. Cad Saúde Pública 2010; 26:1293-302.

25. Orellana JDY, Basta PC, Souza MLP. Mortalidade por suicídio: um enfoque em municípios com alta proporção de população autodeclarada indígena no Estado do Amazonas, Brasil. Rev Bras Epidemiol 2013; 16:658-69.

26. Waiselfisz JJ. Mapa da violência 2011: os jovens do Brasil. http://observatorio.c3sl.ufpr.br/xmlui/ handle/123456789/231 (accessed on 03/Apr/2014). 
27. Laurenti R, Jorge M, Gotlieb SLD. Perfil epidemiológico da morbi-mortalidade masculina. Ciênc Saúde Coletiva 2005; 10:35-46.

28. Minayo MCS. Seis características das mortes violentas no Brasil. Rev Bras Estud Popul 2009; 26:135-40.

29. Secretaria de Atenção à Saúde, Ministério da Saúde. Política Nacional de Atenção Integral à Saúde do Homem (princípios e diretrizes). Brasília: Ministério da Saúde; 2008.

30. Aeron-Thomas A, Jacobs GD, Sexton B, Gururaj G, Rahman F. The involvement and impact of road crashes on the poor: Bangladesh and India case studies. http://r4d.dfid.gov.uk/pdf/outputs/ R7780.pdf (accessed on 24/Oct/2013).

31. Thanh NX, Hang HM, Chuc NTK, Lindholm L. The economic burden of unintentional injuries: a community-based cost analysis in Bavi, Vietnam. Scand J Public Health Suppl 2003; 62:45-51.

32. Centers for Disease Control and Prevention. Medical expenditures attributable to injuries in the U.S., 2000. MMWR Morb Mortal Wkly Rep 2004; 53:1-4.

33. Mesquita Filho M, Mello Jorge MHP. Características da morbidade por causas externas em serviço de urgência Rev Bras Epidemiol 2007; 10:579-91.

34. Freitas EAM, Mendes ID, Oliveira LCM. Ingestão alcoólica em vítimas de causas externas atendidas em um hospital geral universitário. Rev Saúde Pública 2008; 42:813-21.

35. Mohan D, Tiwari G. Injury prevention and control. London/New York: Taylor \& Francis; 2000.

36. Ministério da Saúde. Portaria GM/MS no 737, de 16 de maio de 2001, Institui a Política Nacional de Redução da morbimortalidade por acidentes e violências. Diário Oficial da União 2001; 18 mai.
37. Schramm JMA, Oliveira AF, Leite IC, Valente JG Campos MR, Gadelha AMJ, et al. Transição epidemiológica e o estudo de carga de doença no Brasil. Ciênc Saúde Coletiva 2004; 9:897-908.

38. Costa MFS. Anos de vida perdidos por morte prematura: o efeito de diferentes critérios de correção de sub-registro [Master's Thesis]. Rio de Janeiro: Escola Nacional de Saúde Pública Sergio Arouca, Fundação Oswaldo Cruz; 2007.

39. Souza VR. Anos de vida perdidos por morte prematura por causas externas: análise da tendência e uma proposta metodológica para redistribuição dos códigos-lixo [Master's Thesis]. Rio de Janeiro: Instituto de Medicina Social, Universidade do Estado do Rio de Janeiro; 2012.

40. Murray CJL, Lopez AD. Global health statistics: a compendium of incidence, prevalence, and mortality estimates for over 200 conditions. Cambridge: Harvard University Press; 1996.

41. Murray CJL, Ezzati M, Flaxman AD, Lim S, Lozano R, Michaud C, et al. GBD 2010: a multi-investigator collaboration for global comparative descriptive epidemiology. Lancet 2012; 380:2055-8.

42. World Health Organization. The global burden of disease: 2004 update. Geneva: World Health Organization; 2008.

Submitted on $08 /$ Nov/2013

Final version resubmitted on 16/Jun/2014

Approved on 28/Jul/2014 